\title{
EMO SUBCULTURE IN THE CONTEXT OF DELIBERATE SELF-HARMING
}

\author{
Eliška Janišová
}

\begin{abstract}
The article titled EMO subculture in the context of deliberate self-harming deals with serious risk behaviour particularly in pubescence and adolescence of contemporary children. It could be stated that the subject area of the article, or the topic of deliberate self-harming is generally a taboo, surrounded by some myths for the lay public. The relation of the subculture in question and of deliberate self-harming is surrounded by myths too. The article presents the data acquired by content analysis of selected discussion platforms grouping individuals claiming allegiance to the EMO subculture. The results are confronted with earlier implemented studies.
\end{abstract}

\section{Keywords}

EMO, subculture, deliberate self-harming

\section{Introduction}

The connection of the EMO subculture and deliberate self-harming is an area perceived by the lay public, but also by the professional public through empirical studies - Černá and Šmahel (2009a); Černá and Šmahel (2009b); Kuška, Formánková and Kolářová (2010), etc. It can be stated already at the beginning that such connection has not been proved; and it has not been proved even in empirical studies of the above mentioned authors. But this article chose another method of acquisition of the necessary data (see below) than that used by Černá, Šmahel, Kuška, Formánková and Kolářová.

It is true that the EMO subculture can be subjectively perceived as a declining subculture, but the connection of the EMO subculture and deliberate self-harming persists. 


\section{Deliberate self-harming}

In the broadest meaning, we can view deliberate self-harming as everything by which the individual harms himself/herself or his/her health, both knowingly and unknowingly. The knowingness or unknowingness ${ }^{1}$ of a specific action are determined by the knowledge on the risks resulting from it. In the absolutely broadest meaning, it could include stress, lack of sleep, etc., provided the individual can influence, regulate or manage such things. The definitions of deliberate self-harming describe the given behaviours usually as intentional, physical acts without the intention of dying. The definition by Walsh and Rosen (in Kriegelová, 2008, p. 18) can serve as an example; they define deliberate selfharming as "an individual's behaviour by which he/she harms voluntarily and intentionally his/her own body tissues or body integrity, regardless of health risk or danger and without the intention of dying". This definition includes all attributes of deliberate self-harming. Herpertz (1995) extended the attributes by the repeating act; and in connection with Sutton (2007) who adds that deliberate self-harming is not aimed at sexual satisfaction or aesthetic decoration of the body (tattoo, scarification, piercing, etc.), we can get the concept of deliberate self-harming that constitutes the base for this article. The article draws on the definition by Walsh and Rosen (see above), completed by Sutton and Herpertz.

The literature written in Czech and the Czech authors do not describe the same behaviour by several different terms in this case; the concept of deliberate self-harming is set as "záměrné sebepoškozování" and there are not many synonymous and equivalent terms, there are no confusions and conflicts of opinions about them.

On the contrary, the literature written in English faces another situation; there are several equivalent terms preferred by individual authors. This fact is partially described also by Herpertz (1995). The synonyms most frequently used for the Czech term "záměrné sebepoškozování" are: "Parasuicide", "Self-mutilation", "Self-harming", "Self-injuriours behaviour", "Deliberate self-harm" and other terms.

As the literature written in English has multiple concepts to term deliberate self-harming, the scientific sphere faces a lot of problems related to the results of statistical data on deliberate self-harming. Some authors use even the term "Attempted suicide". The heterogeneous terminology leads to misrepresentation of information and to difficulties in distinguishing deliberate self-harming from suicidal behaviour (Kriegelová, 2008).

The above stated paraphrase can be interpreted as follows. If we focused on making a research entering key words in English, we would get distorted data, according to the preferred name, and such data would not give evidence of the actual number of expert

\footnotetext{
${ }^{1}$ It is of course arguable whether we can view the actions of an individual, who harms himself/herself "somehow" but does not know it, as deliberate self-harming. I personally think that we can. But such facts are determined by the age and the environment in which the individual lives, or by the sociocultural environment, respectively. We can use the example of an individual who reads about a specific "diet" in an internet discussion and therefore leaves out some important foodstuffs. Thus he harms himself due to his unknowingness. The therapy under use of MMS and CDS (bleachers) can be another example.
} 
articles, anthologies and monographs. The issue of self-harming is also dealt with by the World Health Organization (WHO) that, however, relates self-harming noticeably to suicide (WHO, 2015).

To conclude the initial part of the article, it can be stated that in the Czech context, the concept of deliberate self-harming is not understood and perceived with substantial differences. It is thus unanimously defined and unitedly termed -záměrné sebepoškozování (deliberate self-harming). However, in foreign, primarily English speaking countries, the lack of unity of the basic terminology, actually the very designation brings some risks that were described above by the author.

\section{Methods of deliberate self-harming}

Unlike the means of deliberate self-harming, the methods, or ways of deliberate selfharming can be grasped and defined more simply and more exactly. The author will not deal with the means as such, or she will not deal with them within a subchapter, respectively, particularly due to the fact that they are really countless. From different tools to own body to living nature.

"As for the ways of self-harming, they most frequently include cut wounds on the skin, wrist, forearm, back of the hand, scratches, cutting of signs into the skin." This is how Fischer and Škoda define the ways of deliberate self-harming (2009, p. 84).

The content of the definition is poor and unidirectional. It refers to only one of the most frequent ways of self-harming, specifically cutting, which does not capture other selfharming methods, e.g. starvation, skin burning, biting, scalding, etc., that could help to identify more individuals suffering from self-harming. On the other hand, it captures exactly a lay idea of self-harming. The authors state that it is the most frequent method. That is confirmed also by the study made by Ross and Heath (2002, p. 73).

Kriegelová (2008) created a table including the most frequent methods of self-harming (see Table 1). She made the table based on studies by different authors (Hawton, Favezza, Sutton, Arnold), taking place in 1989, 1995, 1999, and 2002.

\section{Table 1 Most frequent methods of deliberate self-harming}

\begin{tabular}{|l|}
\hline Original English terminology. \\
\hline Cutting, self-cutting, slashing. \\
\hline Burning skin by physical means using heat, burning skin by chemical means using caustic liquids. \\
\hline Scalding. \\
\hline Scratching the skin. \\
\hline Scraping/rubbing and cutting the skin, removing the top layer to make a sore. \\
\hline Biting, gnawing at flesh. \\
\hline Giting the inside of the mouth, making sores and regularly re-opening them. \\
\hline Picking the skin. \\
\hline Picking at wounds, interfering whit healing process. \\
\hline
\end{tabular}




\begin{tabular}{|l|}
\hline Original English terminology. \\
\hline Pulling hair out - including eyelashes and eyebrows (Trichotillomania). \\
\hline Hitting themselves hard enough to cause bruises, black eyes, or broken bones. \\
\hline Tying ligatures around the neck, arms or legs to restrict the flow of blood. \\
\hline Ingesting small amounts of toxic substances or objects to cause discomfort and damage but with no intention to die. \\
\hline Placement of sharp objects under the skin or in body orifices. \\
\hline
\end{tabular}

Source: Janišová (2015)

It is evident that the frequency of individual methods of deliberate self-harming is not identical. That is confirmed by the study carried out by Ross and Heath (2002), as well as by other scientific studies.

Although initially, the self-harming individuals use multiple methods of self-harming, they proceed to prefer only one of them after an experimentation period (Favazza \& Conterio, 1989).

\section{Motives of deliberate self-harming}

The subchapter focused on the motives of deliberate self-harming comes significantly closer to the purpose of the article. Unlike the definition of the concept of deliberate selfharming and of the methods of the issue in question, it can observe latent interconnection between the EMO subculture and deliberate self-harming.

There can be dozens, hundreds, even thousands of motives leading to deliberate selfharming; the list below shows that for example stress may be caused by "many" factors, similarly to the fact that discrimination as a motive may have different "motives" of the discriminating ones. All motives cannot be specified in a generalized way. The only, but utopian possibility would consist in making a study with exhaustive selection of all deliberately self-harming individuals.

"Self-hate, serious stress, ventilation of anger and rage, purification, effort for relaxation and calming down, feelings of euphoria, transformation of mental pain into physical pain, survival strategy, negative feelings of own person, depression, being hospitalized, mental pain, disinterest of surrounding persons, suicidal ideas, rape, problems with strain management, effort for bringing inner feelings to the surface, discrimination, bullying, sexual abuse in childhood, sleeplessness, effort for capturing attention of the caretaker, revolt" (Bywaters \& Rolfe, 2002, p. 9). It is not a list of all motives leading to deliberate self-harming and of all functions of deliberate self-harming, identified by the above stated authors. The fragmentary selection made by the author of this article was not determined by any specific procedure.

Kriegelová (2008, p. 110) completes the list with "deliberate self-harming as expression of membership in a group". As the author states, some groups, so called subcultures, consider deliberate self-harming a characteristic of allegiance to their subgroup. Therefore the individual starts self-harming deliberately, to demonstrate loyalty and to show everybody to which subculture he/she belongs. 
The latter quote brings us to the very context of the EMO subculture and deliberate self-harming. In view of the lack of evidence of causality between both variables (see introduction, and more details below), even Kriegelová's statements cannot be interpreted as existence of some connection².

Babáková (2003) states that there is a relation between individuals with behaviour disorders who were living for example in a custody centre and between deliberate selfharming. Thus it is not an impulsive character (see motives and functions by Bywaters \& Rolfe, 2002) but group identification. Similarly, there can be so called "cutting epidemic", consisting in a behaviour of individuals who try to imitate somebody in order to "come under" an elite. Particularly girls show such behaviours. Babáková further states that such behaviours can be found in therapeutic or custody facilities.

Babáková (2003) and Kriegelová (2008) agree that an individual's manifestation of allegiance to a specific subculture can lead to deliberate self-harming. But such forms of deliberate self-harming (piercing, tattoo) do not constitute the topic of this article.

As individual motives and functions of deliberate self-harming are empirically supported, it can be concluded that no direct causality between the EMO subculture and deliberate self-harming was demonstrated. The above stated motives and functions explicitly show that there is probably no interconnection with any other subculture. The question is whether such fact was one of the variables in the given studies, how the respondents were selected, etc. ${ }^{3}$

\section{EMO as subculture}

Subcultures could be defined as organized social groups with common interests or as specific groups related to a broader society or culture. They are, in essence, social groups trying to depart from the standards of the majority group, sharing values and standards that can be perceived by the mainstream society as an element of peculiarity, which is however understandable and natural to the subculture members (Herzog, Mitchell, \& Soccio, 1999; Barker, in Smolík, 2010).

The concept of subculture is very closely related to the concept of subculture of youth. It is a "type of subculture bound to specific behaviours of youth, to their tendency to value preferences, acceptance or rejection of specific standards, life style reflecting the conditions of life" (Smolík, 2010, p. 35).

They are groups of young people, primarily teenagers, connected by an interest, problem, and thus differing from other social groups (Smolík, 2010).

\footnotetext{
2 Kriegelová actually did not have it in mind.

3 The author is aware that some subcultures are related to deliberate self-harming. As the text states, such behaviours include rather tattooing or some initiation rites, etc.
} 
But the majority group identifies them better by external characteristics like clothing and general visual style that need not lead to instant classification in a specific subculture, as the lay public does not know or cannot denominate it. But it leads to clear classification in the group of "other" or even "strange" people.

As Smolík (2010, p. 232) states, we should not classify EMO among subcultures, as it is only about a life style putting emphasis on "image and mental experience"; that is, however, opposed by Šustr $(2009$, p. 18) who advocates the opinion that EMO belongs among subcultures. "In the 1960s already, when the subcultures of youth were created, they became a symbol of generation identity of the youth of that time. The young person demonstrates his/her dissimilarity from, or sometimes even resistance against the majority population by his/her allegiance to a subculture."

It must be stressed that at present, there is some departure from the use of the very concept of subculture. Nevertheless, the concept is still frequently used by expert public (Smolík, 2015).

EMO originated at the turn of the 1980s and 1990s in the punk scene of America. First it was underground, but with the arrival of bands like My Chemical Romance, Panic! At the Disco, 30 second to Mars and others, EMO actually became a worldwide phenomenon of teenagers. The very first mention about EMO was spread by the Rites of Spring band, in 1985, for the Flipside music journal; they stated there that their fans started calling themselves EMO, as they express and show emotions at their concerts. The EMO style originated as a substyle of punk rock that connects the above stated bands. They could be described as playing punk rock, but with EMO style look (Netolická, 2011; Smolík, 2010).

EMO is an abbreviation of "emotive music". "EMO" is based on different music genres, rock, rap, punk, indie, pop and heavy metal (Bailey, 2005).

"The behaviors, attitudes, and values expressed through the music involve emotionally turbulent themes often associated with adolescence such as despair, nostalgia, heartbreak, hope, and self-loathing. [...] For many youth, Emo subculture facilitates identity formation, social interactions, and emotional involvement. It is a place where many adolescents share their experiences about the world and express their feelings about life through music." (Bailey, 2005)

The EMO style is also linked with characteristic dressing style, although it need not be typical to all members claiming allegiance to the given subculture.

Typical features of the dressing style include dark straight hair (usually straightened with hair straightener). They dye their hair black, red or a combination of black with other atypical colours (pink, blue). Both genders often use glasses with thick dark rims. Both genders wear typical black nails, "styled" hair with a forelock, strips, dots, hand covers, badges of different bands and other accessories (Netolická, 2011).

Self-harming is often related to the EMO subculture, primarily thanks to "reading" of different blogs, discussion forums, etc. (Martin, 2006, in Černá \& Šmahel, 2009b). Černá and Šmahel (2009b, p. 30) add that the subculture in question is perceived in that manner primarily by external observers. 


\section{Research methodology}

The data and information were acquired with the help of content analysis, specifically with the help of analysis of documents consisting of websites, discussions and similar platforms focused on the target group. According to Gavora (2006) and others, also photographs or videos presenting "results" or instructions of self-harming behaviour of members of the subculture in question could be used within the content analysis. But such analysis would certainly be more opportune and bring better results of specific persons were observed in specific situations and in broader context. So the results would have a more valid character and could be viewed as a case study, to be adequately completed with other related information.

The content analysis approached as an analysis of documents is based on Hendl's (2008) approach, although the understanding of the actual concept of content analysis can be quite diverse.

Hendl (2008) states that the content analysis should be used as the main research activity only if the necessary data cannot be acquired in another way.

Dvoráková (2010) adds that it is a relatively simple, but primarily objective research method.

It can be added that for some topics, it is a priori the only possible activity (for example topics from the area of the history of pedagogy). For deliberate self-harming of the given subculture, other techniques of data acquisition, primarily interview, are available. But the above stated content analysis was chosen considering the motives of self-harming in the EMO subculture, the age and the general intimacy of the topic. The author was aware of the potential risks resulting from the implementation of the interview; she admits self-critically, that in case of potential (but relatively probable) revelation of the respondent's "forbidden ground", she would not be able to respond adequately and to maintain the interview avoiding harming the respondent.

The analysis of the platforms makes use of open coding. To use axial and selective coding, the author has lack of information, or the results based on axial or selective coding could be misleading, respectively (due to their deficiency).

Thus the categories include:

- motives of deliberate self-harming,

- means of deliberate self-harming,

- methods of deliberate self-harming.

The categories of means of self-harming and methods of self-harming could also constitute one category, with implemented subcategories. Yet the author thinks that for better arrangement, they should be taken as independent categories.

The data do not include the participants' age; it often cannot be found out, but only estimated, which could lead to distortion of the data. At the same time, the data are 
not sorted by genders. The participants' gender cannot always be determined by their nicknames, that may be unisex, or by the text. In some of them, the participant's gender can be distinguished by the style, written in masculine or feminine. As the distinguishing cannot be made at all contributions, the author decided not to sort the acquired data by the two above stated criteria.

\section{Research result}

Based on the methodological aspect of the research, described above, this part of the article presents the results and data acquired by the author.

The discussion platforms were chosen to minimize potential involvement of disinterested individuals. The EMO subculture, primarily its "visual" style, is relatively frequently exposed to different jokes, mockery, humiliation, etc. Any discussions on articles about the EMO subculture e.g. on the idnes.cz or novinky.cz servers can serve as typical examples. The author would like to mention that the idnes.cz or novinky.cz servers can quite evidently not be understood as platforms for association of persons claiming membership or allegiance to the EMO subculture.

Table 2 Motives leading to deliberate self-harming in EMO

\begin{tabular}{|c|c|}
\hline \multicolumn{2}{|c|}{ Motives leading to deliberate self-harming in EMO } \\
\hline \multirow{4}{*}{ Family (8) } & Alcohol in family 1 \\
\hline & Problems with father 1 \\
\hline & $\begin{array}{l}\text { Unsatisfied needs (beating from parents; and when they stopped punishing, she resorted to self-harming, } \\
\text { as a compensation for not being beaten by the parents) } 1\end{array}$ \\
\hline & Not specified 5 \\
\hline \multirow{2}{*}{ School (5) } & Poor marks 2 \\
\hline & Bullying 3 \\
\hline \multirow{7}{*}{ Relations (9) } & Breakup with partner 1 \\
\hline & Problems with establishing relations 1 \\
\hline & Problems in relation 2 \\
\hline & Partner's death 2 \\
\hline & Unlucky in love 1 \\
\hline & Problems with friends 1 \\
\hline & Quarrels 1 \\
\hline \multirow{6}{*}{ Mental problems (7) } & Aversion to life 1 \\
\hline & Mental pain 1 \\
\hline & Hate against oneself 2 \\
\hline & Depression 1 \\
\hline & Feeling of loneliness 1 \\
\hline & Social phobia 1 \\
\hline
\end{tabular}




\begin{tabular}{|l|l|}
\hline Motives leading to deliberate self-harming in EMO \\
\hline \multirow{4}{*}{ Other motives (11) } & Does not remember the cause 3 \\
\cline { 2 - 2 } & Self-harming as an EMO stylish trend 3 \\
\cline { 2 - 2 } & Chasing away boredom 2 \\
\cline { 2 - 2 } & Problems at work 1 \\
\hline Cannot find job 1 \\
\hline TOTAL (40) & Motive not stated 1 \\
\hline
\end{tabular}

Source: Janišová (2015)

Table 2 shows motives ${ }^{4}$ leading to deliberate self-harming in EMO subculture. In the phase of the content analysis, the author of course found several contributions from the same individual. Multiple reasons were not stated in any case. But it can be declared almost certainly that there are individuals who have multiple motives for self-harming and stated only one that was the most significant to them. At the discussion level, the author thinks that the motive of problems with establishing relations can hide for example also problems in the area of sexual identity, appearance, etc. ${ }^{5}$ The table primarily serves to present the ascertained data with the help of simple listing.

The motives included under the highlighted categories lead to one question. Is the EMO subculture a "trigger" of deliberate self-harming, or is it only a place to justify deliberate self-harming? If considering the individual motives (as well as the codes, in our case), all cases actually show relatively common motives, except for one individual who performs self-harming because it is a part of EMO. The motives can be commonly found in problems of children and youth. Individual problems can naturally lead to deliberate self-harming or even to suicide. As the individual categories are relatively balanced, no typical "pattern" (structure) playing the role of a determinative motive, triggering deliberate self-harming of the individual can be captured.

The balanced character of the individual categories is evidenced by statistical calculations. The test value of chi-squared test is 3.27 , as compared to the critical value for 4 degrees of freedom, and the level of significance of 0.05 (9.488) is considerably lower. On this base, it can be stated that there are no statistically significant differences between individual motive categories. The balance can be accentuated by another statistical calculation from the area of data variability that can be used for our nominal (categorial) data. The equal distribution of individual motives in the categories is evidenced also by

\footnotetext{
$\mathbf{4}$ The author understands the motive as the "factor of activation and control of behaviours" (Nuttin, in Nakonečný, 2009, p. 246).

5 No specifically case is meant, but the motive as such, at general level.
} 
the calculation of nominal variance that, with the calculated value of 0.784 , demonstrates almost equal representation of frequencies in individual categories ${ }^{6}$.

Based on this information, potential intervention and prevention from the aspect of focus on specific motives is made more difficult.

But the influence of the determinants affecting the individual's development - family, school, friends (relations) - became obvious. That is, ironically, good news for targeted specific and unspecific primary prevention, as these determinants can be "worked with" within preventive activities.

The author considers it necessary to point out that the preceding two paragraphs are not in mutual discrepancy and do not contradict each other. We know where the prevention can be aimed and, primarily, that it can be predominantly focused on categories of motives that are influenceable; but we must focus on everything, and such fact leads not only to increasing financial costs (from the perspective of the amount and areas of primary-prevention programs), but also to increasing human costs and to generally lower efficiency.

Finally, the author states with respect to the data ascertained and presented in Table 2 , that it is possible to identify a relatively low number of categorized motives (but the individual codes are more dispersed), but the numerical balance does not allow to identify one specific or two significant categories of motives of deliberate self-harming in the EMO subculture.

\section{Table 3 Motives of deliberate self-harming in EMO}

\begin{tabular}{|l|}
\hline Methods of deliberate self-harming in EMO \\
\hline Cutting 31 \\
\hline Burning 2 \\
\hline Scratching 2 \\
\hline Skin perforating 3 \\
\hline Pulling out hairs 1 \\
\hline Self-beating 1 \\
\hline Intoxication 1 \\
\hline Pinching 1 \\
\hline Closing doors on fingers 1 \\
\hline Total $\mathbf{4 3}$ \\
\hline
\end{tabular}

Source: Janišová (2015)

\footnotetext{
${ }^{6}$ The calculation of the necessary data is based on Janiš, K., Jr. (2014). Úvod do problematiky výzkumu I - základy kvantitativního výzkumu: pro studenty oboru Sociální patologie a prevence [Introduction to the Issue of Research I - Basics of Quantitative Research: for Students of Social Pathology and Prevention]. Opava: Faculty of Public Policies in Opava, Silesian University in Opava.
} 
The frequencies found, recorded in Table 3 as simple list of methods of deliberate selfharming in EMO subculture give a considerably more stratified picture as the data in Table 2, and although the data are completed with statistical calculations here too, the conclusion can be quite successfully predicted.

The test value of chi-squared test is $8.39613^{7}$, as compared to the critical value for 1 degrees of freedom, and the level of significance of 0.05 (3.841) is considerably lower. If hypotheses were a part of the study, we would refuse the zero hypothesis related to this issue. So there are statistically significant differences between individual methods, and the method of cutting is most frequently used.

We could make the conclusion that cutting oneself is the typical method of deliberate self-harming in the EMO subculture.

But the ascertained methods allow us making one more conclusion. In general, invasive methods that usually cause disruption of integrity of human skin, thus leaving indelible traces (for some time), prevail. Such information is significant from the aspect of timely intervention and targeted prevention, for potential identification of individuals who cause deliberate self-harm to themselves. We can suppose within discussion again, that individuals with the above stated significant method of deliberate self-harming will hide and mask such activity. Therefore for example the teacher at the elementary or secondary school or the parent should notice that by the end of the school year when the temperatures sometimes exceed $30^{\circ} \mathrm{C}$, some individuals wear long trousers, sweaters, long-sleeved T-shirts, etc. Besides, a visible amount of scars is difficult to explain, unlike bruises that can be blamed on general clumsiness. Cutting wounds for example on the forearm obviously have no relevant justification. But the author must objectively state that the individuals from the EMO subculture can deliberately self-harm themselves on places of their body that can be hidden completely naturally (genitals, thighs, etc.).

It can be assumed that the potential visual identification of individuals of the EMO subculture who chose cutting themselves for deliberate self-harming may be the most essential information for practical use.

Table 4 Means of deliberate self-harming in EMO

\begin{tabular}{|l|}
\hline Means of deliberate self-harming in EMO \\
\hline Razor blade 17 \\
\hline Kitchen knife / knife 6 \\
\hline Scissors 8 \\
\hline Pins 2 \\
\hline Needle 3 \\
\hline Lighter 2 \\
\hline
\end{tabular}

\footnotetext{
7 The value was ascertained by using the characteristics of nominal (categorial) data, with respect to the arranged frequencies, and the method of cutting was compared to all other methods.
} 


\begin{tabular}{|l|}
\hline Means of deliberate self-harming in EMO \\
\hline Matches 2 \\
\hline Glass fragment 3 \\
\hline Nail 1 \\
\hline Kitchen peeler 1 \\
\hline Medicines 1 \\
\hline Compass 1 \\
\hline Not specified 1 \\
\hline Total $\mathbf{4 8}$ \\
\hline
\end{tabular}

Source: Janišová (2015)

The individual means listed in the table above copy almost completely the methods of deliberate self-harming described earlier in this subchapter. But it is evident that some methods do not have their typical means through which the individual, in our case the member of the EMO subculture, self-harms himself/herself. Such methods include selfbeating, pulling out hairs, etc.

In context with the preceding table, the means of medicines seems relatively interesting. It would certainly be very important to identify the specific medicine, not so much with respect to its potential influence on the individual but rather with respect to its availability. That means, whether the medicine is or is not freely available. But as the dominant methods include methods not requiring special "self-harming" means, this information is virtually irrelevant, insignificant or marginal for prevention ${ }^{8}$.

From the perspective of evaluation of the data listed in Table 4 showing the frequencies of individual means, the author states that they correspond to the methods of deliberate self-harming that were ascertained at selected platforms associating discussing individuals claiming allegiance to the EMO subculture. The dominant means of deliberate selfharming of individuals from the EMO subculture include means disrupting the integrity of human body, or skin, respectively.

\section{Conclusion}

It is evident that the ascertained results are limited in some aspects by the selected methodology. It cannot be determined whether the discussing individuals told the truth in their contributions; not all motives of the discussing individuals were identified. In spite of all limits, the ascertained data are in compliance with other studies (see introduction)

\footnotetext{
8 Potential preventive measures in form of "repressive" regulations restricting free availability of some medicines and introducing increased monitoring of distribution and prescription of "on-prescription" medicines.
} 
and offer a base for preparation, planning and implementation of primary prevention. The minimal preventive programs of elementary schools of the Czech Republic contain the topic of subcultures and deliberate self-harming rather exceptionally? ${ }^{9}$. That does not mean that elementary schools do not deal with the issue, or they deal with it rather indirectly. We can see indirect prevention of deliberate self-harming in primary prevention aimed at offering information about help (Safety Hot Line, etc.). Similarly, the minimal preventive programs contain an area that can be called paying attention to changes in pupils' behaviour. The author believes that we do not need to name explicitly the risk behaviour in question within the implemented primary prevention. She takes as base the data and comments related to Tables 2, 3 and 4. She believes that, unfortunately, the primary prevention in relation to deliberate self-harming is insufficient.

Finally, the author will mention one more relation between primary prevention and deliberate self-harming in the environment of elementary schools. She believes that the teachers can be significantly involved in reducing its incidence by building the relation between them and the pupils.

\section{References}

Babáková, L. (2003). Sebepoškozování v dětství a adolescenci [Selfmutilation in Childhood and Adolescency]. Psychiatrie pro praxi [Psychiatry for Practice], 2003(4), 165169. Retrieved from http://www.psychiatriepropraxi.cz/pdfs/psy/2003/04/05.pdf

Bailey, B. (2005). Emo Music and Youth Culture. In S. Steinberg, P. Parmar, \& B. Richard (Eds.), Contemporary Youth Culture: An International Encyclopedia (pp. 338-343). Westport, CT: Greenwood Press.

Bendová, A. (2016). Trídní učitel v sociálních vztazích se svými žáky: případová studie [The Class Teacher in Social Relationships with the Pupils: A Case Study]. Pedagogická orientace [Pedagogical Orientation], 26(4), 252-271.

Bywaters, P., \& Rolfe, A. (2002). Look beyond the scars: Understanding and responding to self-injury and self-harm. Retrieved from http://www.brown.uk.com/selfinjury/selfharm. pdf

Černá, A., \& Šmahel, D. (2009a). Sebepoškozování v adolescenci: blog jako prostředek vytváření komunity [Self-Injury in Adolescence: Blogging as a Means of Creating Community]. Československá psychologie [Czechoslovak Psychology], 53(5), 492-504.

\footnotetext{
${ }^{9}$ They contain virtually no connection of subcultures and deliberate self-harming.
} 
Černá, A., \& Šmahel, D. (2009b). Sebepoškozování v adolescenci: kontext reálného a virtuálního prostředí a subkultur EMO a Gothic [Self-Injury in Adolescence: Context of Real and Virtual Environments and EMO and the Gothic Subcultures]. E-psychologie, 3(4), $26-44$.

Dvořáková, I. (2010). Obsahová analýza/formální obsahová analýza/kvantitativní obsahová analýza [Content analysis/formal content analysis/quantitative content analysis]. AntropoWebzin, 3(2), 95-99. Retrieved from http://antropologie.zcu.cz/media/ webzin/webzin_2_2010/Dvorakova_I-2-2010.pdf

Favazza, A. R., \& Conterio, K. (1989). Female habitual self-mutilators. Acta Psychiatrica Scandinavica, 79(3), 283-289.

Gavora, P. (2006). Sprievodca metodológiou kvalitatívneho výskumu [A Quality Methodological Research Guide]. Bratislava: Regent.

Herpertz, S. (1995). Self-injurious behaviour: psychopathological and nosological characteristics in subtypes of self-injurers. Acta Psychiatrica Scandinavica, 91(1), 57-68. Retrieved December 10, 2014, from http://onlinelibrary.wiley.com/ doi/10.1111/j.1600-0447.1995.tb09743.x/pdf

Herzog, A., Mitchell, J., \& Soccio, L. (1999). Interrogating Subcultures. Invisible culture: an electronic journal for visual studies, 1999(2). Retrieved February 26, 2015, from http:// www.rochester.edu/in_visible_culture/issue2/introduction.htm

Janiš, K., Jr. (2014). Úvod do problematiky výzkumu I - základy kvantitativního výzkumu: pro studenty oboru Sociální patologie a prevence [Introduction to the Issue of Research I - Basics of Quantitative Research: for Students of Social Pathology and Prevention]. Opava: Faculty of Public Policies in Opava, Silesian University in Opava.

Janiš, K., Jr., Janišová, E., \& Skopalová, J. (2015). Záměrné sebepoškozování-nezapomněli jsme na něco? [Deliberate Self-Injury - Have We Not Forgotten Something?]. Prevence [Prevention], 12(9), 14-17.

Janišová, E. (2015). Záměrné sebepoškozování u vybraných subkultur [Deliberate Selfharming at Chosing Subcultures] (bachelor's thesis). Opava: Silesian University in Opava, Faculty of Public Policies in Opava.

Kriegelová, M. (2008). Záměrné sebepoškozování v dětství a adolescenci [Deliberate Self-Injury Childhood and Adolescence]. Prague: Grada.

Kuška, M., Formánková, P., \& Kolářová, K. (2010). Subkultura emo kids jako fenomén současné konzumní společnosti [The EMO Kids Subculture as a Phenomenon of the 
Current Consumerist Society]. In K. Zábrodská, \& I. Čermák (Eds.), Kvalitativní přístup a metody ve vědách o člověku IX. Individualita a jedinečnost v kvalitativním výzkumu [The Qualitative Approach and Methods in Human Sciences IX. Individuality and Uuniqueness in Qualitative Research] (pp. 370-374). Brno: The Institute of Psychology of Academy of Science of Czech Republic.

Nakonečný, M. (2009). Psychologie osobnosti [Psychology of Personality]. Prague: Academia.

Netolická, D. (2011). Jsem EMO... [I am EMO...]. Prevence [Prevention], 8(6), 6-8.

Ross, S., \& Heath, S. (2002). A Study of the Frequency of Self-Mutilation in a Community Sample of Adolescents. Journal of Youth and Adolescence, 31(1), 67-77.

Smolík, J. (2010). Subkultury mládeže: uvedení do problematiky [Youth Subcultures: Introduction to the Issue]. Prague: Grada.

Smolík, J. (2015). Subkultury mládeže: Od deviace k fragmentaci [Youth Subcultures: From Deviation to Fragmentation]. Sociální pedagogika [Social Pedagogy], 3(1), 3655. Retrieved from http://soced.cz/wp-content/uploads/2015/04/STUDIE_Subkulturyml\%C3\%A1de\%C5\%BEe.-Od-deviace-k-fragmentaci_Final.pdf

Sutton, J. (2007). Healing The Hurt Within: Understand Self-injury and Self-harm, and Heal the Emotional Wounds. Oxford: How to Books.

Šustr, J. (2009). Emo styl jako subkultura? [The EMO Style as a Subculture?]. Rodina a škola [Family and School], 56(5), 18-19.

WHO. (2015). Assessment for self harm/suicide in persons with priority mental, neurological and substance use disorders. Retrieved January 7, 2015, from http://www. who.int/mental_health/mhgap/evidence/suicide/q1/en/

WHO. (n.d.). Self harm and suicide. Retrieved January 26, 2015, from http://www.who. int/mental_health/mhgap/evidence/suicide/en/

\section{Author}

Mgr. Eliška Janišová

Primary School Bartošovice

Bartošovice 147, 74254 Bartošovice, Czech Republic

eliska.janisova@gmail.com 